\title{
Cultivating spiritual resources for improving undergraduate student's mental health
}

\author{
Irwan Nuryana Kurniawan \\ Universitas Islam Indonesia, Yogyakarta, Indonesia \\ *Corresponding author, e-mail: kurniawan-in@uii.ac.id
}

\begin{abstract}
The increasing number of students coming to the university' s guidance and counselling unit demonstrates the need for more serious and systemic efforts to deal with students' mental health. Previous studies have shown that religion has significant contribution to the human mental health and psychological well-being. This study specifically examined the role of one of the spiritual resources that get emphasis in Islamic teachings that is "Tawakal toward Allah SubhanahuwaTa' ala" to the undergraduate students' mental health. To test the research hypothesis that asserted there is a positive relationship between surrender to God and socialemotional health, current study uses correlational design. The study involved 57 undergraduate students of the statistic class at Psychology Department of Islamic University of Indonesia, Yogyakarta and Surrender to God Scale (Wong-McDonald \& Gorsuch, 2000) and Social-Emotional Health Survey (Furlong, You, Shishim, \& Dowdy, 2017) were administered to them. When social desirability on the relationship between surrender to God and social-emotional health was controlled, partial correlation $\mathrm{r}(56)=.510, \mathrm{p}=.001$ was found.The result suggests that there was a significant and strongly positive association between surrender to God and students' socialemotional health when controlling social desirability scores
\end{abstract}

Keywords: Surrender to God, Social-Emotional Health, Undergraduate students.

How to Cite: Kurniawan, I. N. (2018). Cultivating spiritual resources for improving undergraduate students mental health. International Journal of Research in Counseling and Education, 2 (2) 64 - 70 , https://doi.org/10.24036/0024za0002

\section{Introduction}

Although all higher education institutions recognize and consider the importance of mental health for the success of their student studies, some universities (Clapham, Jahchan, Medves, Tierney, \& Walker, 2012; Report, 2008) report that mental health is still a concerning issue on their campus.The problems ranging from stress, anxiety, until diagnosed depression disorder (Beiter et al., 2014; Hussain, Guppy, Robertson, \& Temple, 2013; Macaskill, 2012). Whereas mental health problems such as depression related to poor quality in behaviour, social relationships, and academic performance of undergraduate students(Keyes, 2009). Likewise, stress is found to have negative impact on physical health, mental health, and academic achievement(Shankar \& Park, 2016).

In contrast to the above studies that view mental health as the absence of disease, disorder, and disability, current research uses positive mental health concept that emphasizes more on the presence of assets, strengths, and positive attributes. Individual free of mental illness are not necessarily mentally healthy(Keyes, 2009, 2014). In other words, problem-free does not mean fully prepared (Pittman, 1992). In fact, the concept of positive mental health was adopted by World Health Organization (WHO) and now mental health is defined as a state of well-being in which individual realizes his or her own abilities, can cope with the normal of stresses of life, can work productively and fruitfully, and is able to make a contribution to his or her community (World Health Organization, 2004).

More specifically, current study uses a mental health model called covitality, a positive construct that is a result of the interplay among co-occurring positive psychological health indicators (Jones, You, \& Furlong, 2013). The covitality mental health model sees adolescents as actively constructing a worldview of who they are and coming to conclusion about their fit within their social contexts. The covitalitymodel posits of four 
core mental health domains (belief in self, belief in others, emotional competence, and engaged living) and each domain is composed of three positive psychological building blocks (self-awareness, persistence, and self-efficacy for belief in self domain; family support, peer support, and institutional support for belief in others domain; cognitive reappraisal, empathy, and self-regulation for emotional competence domain; optimism, zest, and gratitude for engaged living domain)(Renshaw et al., 2014).

If previous studies have offered religiosity (Abdel-Khalek, 2007; Snider \& McPhedran, 2014; Tiliouine, Cummins, \& Davern, 2009)in more macro context or religious coping (Aflakseir \& Coleman, 2009; Gardner \& Krägeloh, 2013; Olson, Trevino, Geske, \& Vanderpool, 2012)in more micro context as a solution to understand undergraduate students' mental health variability, the present study is trying to offer a more specific solution, Surrender to God.Surrender to God, a religious coping strategy in which individual actively chooses what God wants, choices, and decisions as the best will, choice, and decision for him or her (Wong-McDonald \& Gorsuch, 2000), is found to be a significant predictor for spiritual outcome and changesin patients' physical and mental health (Pargament, Koenig, Tarakeshwar, \& Hahn, 2004).

In the setting of college students' lives, Clements \& Ermakova (2012)found Surrender to God to be significantly negatively related to state anxiety and trait anxiety, even when controlling for demographic variables. Undergraduate students high in Surrender to God tend to have lower reported stress and therefore should be at lowered risk for stress-related health problems. This finding support that Surrender to God could be one mechanism by which religiosity prevents disease and therefore contributes to healthiness. WongMcDonald \& Gorsuch (2004) asserted that individuals who report willingness to Surrender to God would be likely to trust God benevolence and control, having their locus of control in God rather than themselves, thus either reducing the individual' $s$ need to feel stress over adversity or reducing the likelihood of the individual being in the stressful situation due against to their religious scriptures.

People with high in Surrender to God try to find the wisdom behind the difficulties encountered, by surrendering completely to God' s guidance. When remembering the difficulties, they have experienced, they feel grateful to God who has given them lessons through those difficulties. They choose to be steadfast because and with God, even though such things can make them perceived as weak by their environment. When worried, sad, or panicked, their future optimism is renewed as they behave and act according to God' s guidance (Wong-McDonald \& Gorsuch, 2000). Those who put their trust in Allah SubahanahuwaTa' ala are satisfied with whatever the gift Allah Ta' aladan His Messenger (QS At-Taubah [9]:59) and are content with everything God has given him for believing Allah Almighty who is in complete control and has already determined for everything a decreed extent (QS Ath-Thalaq [65]:3). They do not feel anxious about the sustenance they get (QS Al-Ankabut [29]:60) because they believe that everything the unseen aspects of the heavens and the earth belongs to God and they return all their affairs to Allah (QS Huud [11]:23).

The current studies aim to verify the relationship between Surrender to God and reported positive mental health amongst a sample of undergraduate students Universitas Islam Indonesia. It is hypothesized that there will be a positive correlation between Surrender to God and positive mental health.

\section{Method}

One convenience samples of 59 undergraduate students ofPsychology Department, Universitas Islam Indonesia were recruited. They were 16 male and 43 female, with mean age of $19.3(\mathrm{SD}=.81)$, and enrolled in Statistic for Psychology class.

Surrender to God is revealed using the 12-items Surrender Scale(SS; Wong-McDonald \& Gorsuch, 2000) that was developed to ask for information about behaviours and thoughts related to degree to which people are willing to surrender to God, such as " When my solutions to problems are in conflict with God' s alternatives, I will submit to God' s way." Response choices for all items range from 1 (never true of me) to 5 (always true of me). For Indonesian version (Sartika \& Kurniawan, 2015), the SS has a reliability coefficient of .90 and .83 for current study.

Mental health is measured using the 36-items Social Emotional Health Survey-Higher Education (SEHSHE; Furlong et al., 2017), a multidimensional measure of covitality (the co-occurrence of positive intrapersonal assets and interpersonal resources, the combination of which increase the odds of a youth having positive developmental outcomes and robust psychological well-being) and consisted of four latent traits (each comprised three measured subscales): belief-in-self (subscales: self-efficacy, persistence, selfawareness), belief-in-others (subscales: family support, institutional support, peer support), emotional competence (subscales: cognitive reappraisal, empathy, self-regulation),and engaged living (subscales: gratitude, zest, optimism). In contrast to the original initial response option for all items range from 1 (very much unlike me) to 6 (very much like me), then in current study it is modified to be 1 (never true of me) to 5 
(always true of me). For Indonesian version(Uyun \& Kurniawan, 2017), the SEHS-HE has reliability coefficient of .92 and .87 for present study.

Social desirability is disclosed using 11-items Short Form of the Marlowe-Crowne Social Desirability Scale (MCSDS-SF; Reynolds, 1982) that was developed to inquire about the tendency of individuals to present themselves favourably with respect to current social norms and standards, such as "I am always courteous, even to people who are disagreeable" . To obtain a socially desirable answer, 3 items require an affirmative response and 8 items need a negative response. For Indonesia version ((Uyun\& Kurniawan, 2017), the MCSDS-SF has reliability coefficient of .84 and .72 for current study.

The three questionnaires in Indonesian version were administered anonymously to students during statistic for psychology class sessions and the return rates was 100\%. Descriptive statistics and partial correlation statistics were used to answer the objective of the current study.

\section{Results and Discussion}

Tabel 1

Partial Correlation Between Surrender to God and Social Emotional Health by Controlling Social Desirability

\begin{tabular}{ll}
\hline & Surrender to God $(\mathrm{r}(\mathrm{df})=)$ \\
\hline Social Emotional Health & $\mathrm{r}(56)=.51^{* * *}$ \\
Belief-in-Self & $\mathrm{r}(56)=.35^{* *}$ \\
Self-Efficacy & $\mathrm{r}(56)=.20$ \\
Persistence & $\mathrm{r}(56)=.20$ \\
Self-Awareness & $\mathrm{r}(56)=.33^{* *}$ \\
Belief-in-Others & $\mathrm{r}(56)=.33^{* *}$ \\
Family Support & $\mathrm{r}(56)=.31^{*}$ \\
Institutional Support & $\mathrm{r}(56)=.15$ \\
Peer Support & $\mathrm{r}(56)=.29^{*}$ \\
Emotional Competence & $\mathrm{r}(56)=.49^{* * *}$ \\
Cognitive Reappraisal & $\mathrm{r}(56)=.46^{* * *}$ \\
Empathy & $\mathrm{r}(56)=.32^{* *}$ \\
Self-Regulation & $\mathrm{r}(56)=.31^{*}$ \\
Engaged Living & $\mathrm{r}(56)=.41^{* *}$ \\
Gratitude & $\mathrm{r}(56)=.39^{* *}$ \\
Zest & $\mathrm{r}(56)=.19$ \\
Optimism & $\mathrm{r}(56)=.40^{* *}$ \\
*** Correlation is significant at level .001 (1-tailed) & \\
$* *$ Correlation is significant at level .01 (1-tailed) & \\
$*$ Correlation is significant at level .05 (1-tailed) & \\
& \\
\hline
\end{tabular}

As hypothesized and using Cohen'sreference (1992) for interpretation of a correlation coefficient, partial correlational matrices informed a strong and significant positive correlation between Surrender to God scores and social emotional health scores (see Table 1). It means, after controlling social desirability variable, $26.01 \%$ of the variation in the undergraduate students' positive mental health can be attributed to their Surrender to God. 
When analysed further, Surrender to God has a moderate and significant positive correlation with the four dimensions of positive mental health (See Table 1). Surrender to God shows the strongest correlation with emotional competence dimension, followed successively the relationship between Surrender to God and engaged living, Surrender to God and belief-in-self, Surrender to God and belief-in-others. Table 1 also indicated that the strength of the correlation between Surrender to God and 12 positive psychological building blocks is diverse, ranging from weak relationship (e.g., between Surrender to God and peer support) to moderate relationship (e.g., between Surrender to God and cognitive reappraisal).

When considering the gender factor, the strength of the correlation between Surrender to God and positive mental health show different results (see Table 2). After controlling social desirability tendency, $42.25 \%$ of the variation in the female undergraduate students' positive mental health can be explained by their Surrender to God while in the male undergraduate students only $5.29 \%$. Except the positive mental dimension of belief-in-others, the same pattern is also found that in the strength of the relationship between the two variables higher among female undergraduate student participants than male undergraduate students.

Tabel 2

Partial Correlation Between Surrender to God and Social Emotional Health by Controlling Social Desirability

\begin{tabular}{|l|l|l|}
\hline \multirow{2}{*}{} & \multicolumn{2}{|l|}{ Surrender to God $(\mathrm{r}(\mathrm{df})=)$} \\
\cline { 2 - 3 } & Female & Male \\
\hline Social Emotional Health & $\mathrm{r}(40)=.65^{* * *}$ & $\mathrm{r}(13)=.23$ \\
\hline Belief-in-Self & $\mathrm{r}(40)=.53^{* * *}$ & $\mathrm{r}(13)=-.24$ \\
\hline Self-Efficacy & $\mathrm{r}(40)=.40^{* *}$ & $\mathrm{r}(13)=-.08$ \\
\hline Persistence & $\mathrm{r}(40)=.32^{*}$ & $\mathrm{r}(13)=-.31$ \\
\hline Self-Awareness & $\mathrm{r}(40)=.40^{* *}$ & $\mathrm{r}(13)=.16$ \\
\hline Belief-in-Others & $\mathrm{r}(40)=.33^{*}$ & $\mathrm{r}(13)=.46^{*}$ \\
\hline Family Support & $\mathrm{r}(40)=.36^{*}$ & $\mathrm{r}(13)=.19$ \\
\hline Institutional Support & $\mathrm{r}(40)=.15$ & $\mathrm{r}(13)=.32$ \\
\hline Peer Support & $\mathrm{r}(40)=.25$ & $\mathrm{r}(13)=.56^{*}$ \\
\hline Emotional Competence & $\mathrm{r}(40)=.66^{* * *}$ & $\mathrm{r}(13)=.44$ \\
\hline Cognitive Reappraisal & $\mathrm{r}(40)=.60^{* * *}$ & $\mathrm{r}(13)=.43$ \\
\hline Empathy & $\mathrm{r}(40)=.42^{* *}$ & $\mathrm{r}(13)=.11$ \\
\hline Self-Regulation & $\mathrm{r}(40)=.36^{*}$ & $\mathrm{r}(13)=.47^{*}$ \\
\hline Engaged Living & $\mathrm{r}(40)=.58^{* * *}$ & $\mathrm{r}(13)=-.05$ \\
\hline Gratitude & $\mathrm{r}(40)=.48^{* *}$ & $\mathrm{r}(13)=-.04$ \\
\hline Zest & $\mathrm{r}(40)=.40^{* *}$ & $\mathrm{r}(13)=-.28$ \\
\hline Optimism & $\mathrm{r}(40)=.46^{* *}$ & $\mathrm{r}(13)=.27$ \\
\hline$* * *$ Correlation is significant at level $.001(1-\mathrm{tailed})$ & \\
\hline$* *$ Correlation is significant at level $.01(1-\mathrm{tailed})$ & \\
\hline Correlation is significant at level $.05(1-\mathrm{tailed})$ & \\
\hline
\end{tabular}

The purpose of the study who want to know the relationship between Surrender to God and mental health of undergraduate students get empirical support in this study. The research hypothesis states that there is a positive relationship between Surrender to God and mental health is accepted (see Table 1). This 
means that students' variability in Surrender to God has a strong relationship with the variability of their mental health.

The present research findings are in line with previous studies on the positive role of religious coping on human mental health (Hebert, Zdaniuk, Schulz, \& Scheier, 2009; Olson et al., 2012), both on Muslim samples (Aflakseir \& Coleman, 2009; Ai, Peterson, \& Huang, 2003; Gardner \& Krägeloh, 2013)and non-Muslim samples(Hebert et al., 2009; Pargament et al., 2004). Religious beliefs and practices may help people to better cope with stressful life circumstances and give them comfort, meaning, a sense of control, and hope (Weber \& Pargament, 2014). People who believe they had a closer relationship with God and prayed more frequently reported significantly greater life satisfaction and somewhat greater happiness than other people did.

In a broader context, current research findings reinforce the links of religiousness with health, well-being, and social behaviour (McCullough \& Willoughby, 2009). Religion promotes self-control and influences how goals are selected, pursued, and organized. Religion facilitates self-monitoring, prescribes and fosters proficiency in a suite of self-regulatory behaviours. Some of religion' s influences on health, well-being, and social behaviour may results from religion' $s$ influences on self-control and self-regulation (McCullough \& Willoughby, 2009).

In Islam perspective, people who put their trust in God are supposed to have high positive mental health because their hearts will not be shaken and anxious when their preferred cause disappears and something they don' t like is coming. They surrender themselves to the provision and decrees of God, while keeping all His commandments and surrendering to Him in every circumstances, accompanied by the attempt to sever all the relationships of the heart to other than God(At-Tuwaijiri, 2014). They think positively to God because the sequence of events occurring in the world life is subject to God will. God did according to His will. Something that is considered good can be bad and otherwise something bad is good. They believe all matters back to God and they surrender entirely their affairs to God(Khaled, 2012).

\section{Conclusion}

Undergraduate students' mental health variability can be significantly explained by the surrender to God variability. The strength of the relationship between surrender to God and undergraduate students' mental health varies according to gender factors

\section{Acknowledgment}

Many thanks to all statistic class students who volunteer to participate in this research project. RidhaHabibah and Izdatunnida who has helped me much with the study, and Hasan Mangkualamwho provided technical help.

\section{References}

Abdel-Khalek, A. M. (2007). Religiosity, happiness, health, and psychopathology in a probability sample of Muslim adolescents. Mental Health, Religion and Culture, 10(6), 571- 583. https://doi.org/10.1080/13674670601034547

Aflakseir, A., \& Coleman, P. G. (2009). The influence of religious coping on the mental health of disabled Iranian war veterans. Mental Health, Religion and Culture, 12(2), 175- 190. https://doi.org/10.1080/13674670802428563

Ai, A. L., Peterson, C., \& Huang, B. (2003). The effect of religious-spiritual coping on positive attitudes of adult Muslim refugees from Kosovo and Bosnia. The International Journal for the Psychology of Religion, 13(1), 29- 47. https://doi.org/10.1207/S15327582IJPR1301

At-Tuwaijiri, S. M. bin I. bin A. (2014). Ensiklopedia manajemen hati (Jilid 2). (T. D. Sunnah, Ed.) (1st ed.). Jakarta: Darus Sunnah Press. Retrieved from www.darus-sunnah.com

Ardi, Z., \& Sukmawati, I. (2017). Social Media and the Quality of Subjective Well-Being; Counseling Perspective in Digital Era. Open Science Framework. October, 15.

Beiter, R., Nash, R., Mccrady, M., Rhoades, D., Linscomb, M., Clarahan, M., \& Sammut, S. (2014). The prevalence and correlates of depression, anxiety, and stress in a sample of college students. Journal of Affective Disorders, 173, 90- 96. https://doi.org/10.1016/j.jad.2014.10.054 
Clapham, L., Jahchan, R., Medves, J., Tierney, A., \& Walker, D. (2012). Student mental health and wellness: Framework and recommendations for a comprehensive strategy. Retrieved from http://www.queensu.ca/principal/sites/webpublish.queensu.ca.opvcwww/files/files/CMHFinalReport.pd $\mathrm{f}$

Clements, A. D., \& Ermakova, A. V. (2012). Surrender to God and stress: A possible link between religiosity and health. Psychology of Religion and Spirituality, 4(2), 93- 107. https://doi.org/10.1037/a0025109

Cohen, J. (1992). A power primer. Psychological Bulletin [PsycARTICLES, 112(1), 155- 159. Retrieved from http://www2.psych.ubc.ca/ schaller/528Readings/Cohen1992.pdf

Furlong, M. J., You, S., Shishim, M., \& Dowdy, E. (2017). Development and validation of the Social Emotional Health Survey- Higher Education Version. Applied Research in Quality of Life, 12(2), 343- 367. https://doi.org/10.1007/s11482-016-9464-9

Gardner, T. M., \& Krägeloh, C. U. (2013). Religious coping , stress , and quality of life of Muslim university students in New Zealand. Mental Health, Religion \& Culture, (August), 37- 41. https://doi.org/10.1080/13674676.2013.804044

Hebert, R., Zdaniuk, B., Schulz, R., \& Scheier, M. (2009). Positive and negative religious coping and well-being in women with breast cancer. Journal of Palliative Medicine, 12(6), 537-545. Retrieved from https://www.ncbi.nlm.nih.gov/pmc/articles/PMC2789454/pdf/jpm.2008.0250.pdf

Hussain, R., Guppy, M., Robertson, S., \& Temple, E. (2013). Physical and mental health perspectives of first year undergraduate rural university students. BMC Public Health, 13, 1. https://doi.org/10.1186/14712458-13-848

Jones, C. N., You, S., \& Furlong, M. J. (2013). A preliminary examination of covitality as integrated well-being in college students. Social Indicators Research, 111(2), 511- 526. https://doi.org/10.1007/s11205-0120017-9

Keyes, C. L. M. (2009). The nature and importance of mental health in America' s adolescence. In M. J. Furlong, R. Gilman, \& E. S. Huebner (Eds.), Handbook of Positive Psychology in Schools (pp. 9- 25). New York: $\quad$ Routledge. $\quad$ Retrieved from https://books.google.co.id/books?hl=en\&lr=\&id=1pKOAgAAQBAJ\&oi=fnd\&pg=PA9\&dq=The+nature+and+ importance+of+positive+mental+health+in+America\%27s+adolescence\&ots=9KnMmnBK94\&sig=7d7GD OZk5G62CICh6a9X3I7r7rU\&redir_esc=y\#v=onepage\&q=The nature and importan

Keyes, C. L. M. (2014). Mental health as a complete state: How the salutogenic perspective completes the picture. In G. . Bauer \& O. Hämmig (Eds.), Bridging occupational, organizational and public health: A transdisciplinary approach (pp. 179- 192). Springer Science. https://doi.org/10.1007/978-94-007-56403_11

Khaled, A. (2012). Buku pintar akhlak: Memandu Anda berkepribadian Muslim dengan lebih asyik, lebih otentik. (H. Subagyo \& I. Sibawaih, Eds.) (4th ed.). Jakarta: Zaman. Retrieved from www.penerbitzaman.com

Macaskill, A. (2012). The mental health of university students in the United Kingdom. British Journal of Guidance and Counselling, 41(4), 426- 441. Retrieved from http://shura.shu.ac.uk/6449/

McCullough, M. E., \& Willoughby, B. L. B. (2009). Religion, self-regulation, and self-control: Associations, explanations, and implications. Psychological Bulletin, 135(1), 69- 93. https://doi.org/10.1037/a0014213

Olson, M. M., Trevino, D. B., Geske, J. A., \& Vanderpool, H. (2012). Religious coping and mental health outcomes: An exploratory study of socioeconomically disadvantaged patients. Explore: The Journal of Science and Healing, 8(3), 172- 176. https://doi.org/10.1016/j.explore.2012.02.005

Pargament, K. I., Koenig, H. G., Tarakeshwar, N., \& Hahn, J. (2004). Religious coping methods as predictors of psychological, physical and spiritual outcomes among medically Ill elderly patients: A two-year longitudinal study. Journal of Health Psychology Www.sagepublications.com, 9(6), 713- 730. https://doi.org/10.1177/1359105304045366

Pittman, K. (1992). Let' s make youth work a field. Retrieved February 8, 2018, from http://forumfyi.org/content/youth-today-lets-make-

Renshaw, T. L., Furlong, M. J., Dowdy, E., Rebelez, J., Smith, D. C., O' Malley, M., ... Strom, I. F. (2014). Covitality: A synergistic conception of adolescents' mental health. In M. J. Furlong, R. Gilman, \& E. S. 
Huebner (Eds.), Handbook of Positive Psychology in the Schools (2nd ed., pp. 12- 32). New York, NY: Routledge/Taylor \& Francis.

Report, T. F. (2008). Student mental health and well-being. Stanford, CA . Retrieved from https://wellness.stanford.edu/sites/default/files/taskforce_report.pdf

Reynolds, W. M. (1982). Development of reliable and valid short forms of the Marlowe-Crowne Social Desirability Scale. Journal of Clinical Psychology, 38(1), 119- 125.

Sartika, A., \& Kurniawan, I. N. (2015). Skala Tawakal kepada Allah: Pengembangan ukuran-ukuran psikologis surrender to god dalam perspektif Islam. Psikologika : Jurnal Pemikiran Dan Penelitian Psikologi, 20(2), 129- 142. Retrieved from http://jurnal.uii.ac.id/index.php/Psikologika/article/view/7727

Shankar, N. L., \& Park, C. L. (2016). Effects of stress on students' physical and mental health and academic success. International Journal of School \& Educational Psychology, 4(1), 5- 9. https://doi.org/10.1080/21683603.2016.1130532

Snider, A.-M., \& McPhedran, S. (2014). Religiosity, spirituality, mental health, and mental health treatment outcomes in Australia: A systematic literature review. Mental Health, Religion \& Culture, 17(6), 568581. https://doi.org/http://dx.doi.org/10.1080/13674676.2013.871240

Tiliouine, H., Cummins, R., \& Davern, M. (2009). Islamic religiosity, subjective well-being, and health. Mental Health, Religion and Culture, 12(1), 55- 74. https://doi.org/10.1080/13674670802118099

Uyun, Q., \& Kurniawan, I. N. (2017). Terapi taubat dan istighfar sebagai intervensi untuk memperbaiki kesehatan mental mahasiswa. Yogyakarta.

Weber, S. R., \& Pargament, K. I. (2014). The role of religion and spirituality in mental health. Current Opinion in Psychiatry, 27(5), 358- 363. https://doi.org/10.1097/YCO.0000000000000080

Wong-McDonald, A., \& Gorsuch, R. L. (2000). Surrender to god: An additional coping style? Journal of Psychology and Theology, 28(2), 149- 161.

Wong-McDonald, A., \& Gorsuch, R. L. (2004). A multivariate theory of God concept, religious motivation, locus of control, coping, and spiritual well-being. Journal of Psychology and Theology, 3(4), 318- 334.

World Health Organization. (2004). Promoting mental health: Concepts, emerging evidence, and practice. Geneva. Retrieved from http://www.who.int/mental_health/evidence/en/promoting_mhh.pdf 